Relations industrielles

Industrial Relations

\title{
Quarter, Jack, Crossing the Line: Unionized Employee Ownership and Investment Funds
}

\section{Richard J. Long}

Volume 51, numéro 4, 1996

URI : https://id.erudit.org/iderudit/051139ar

DOI : https://doi.org/10.7202/051139ar

Aller au sommaire du numéro

Éditeur(s)

Département des relations industrielles de l'Université Laval

ISSN

0034-379X (imprimé)

1703-8138 (numérique)

Découvrir la revue

Citer ce compte rendu

Long, R. J. (1996). Compte rendu de [Quarter, Jack, Crossing the Line: Unionized Employee Ownership and Investment Funds]. Relations industrielles / Industrial Relations, 51(4), 845-847. https://doi.org/10.7202/051139ar

Tous droits réservés (C Département des relations industrielles de l'Université Laval, 1996
Ce document est protégé par la loi sur le droit d'auteur. L'utilisation des services d'Érudit (y compris la reproduction) est assujettie à sa politique d'utilisation que vous pouvez consulter en ligne.

https://apropos.erudit.org/fr/usagers/politique-dutilisation/ 


\section{Recensions}

\section{Book Reviews}

\section{Crossing the Line: Unionized Employee Ownership and Investment Funds}

by Jack QUARTER, Toronto, James Lorimer and Company, 1995, 215 p., ISBN 1-55028-457-6 (bond) and ISBN 1-55028-456-8 (pbk).

In this book, Jack Quarter attempts to paint a picture of a new phenomenon in Canada: the merging of labour and capital. He argues that this "crossing the line" between labour and capital is taking place in three main forms: outright buyouts by unionized workers of their employer, ownership by unionized employees of some portion of their employer's stock, and labour investment funds. Each of these phenomena, he argues, has the potential to transform the traditional relationship between labour and capital in Canada.

Of course, these three phenomena are quite different. There is an enormous difference between firms in which the employees own a majority of the voting shares, and the thousands of cases where employees own a relatively small proportion of the shares. And labour investment funds really have nothing at all to do with employee ownership, since the great majority of the investors in these funds are not employees of the firms in which these funds invest. Indeed, any citizen of a province in which these funds are registered may invest in them, and many thousands have, often drawn by the very favourable tax benefits which accompanied these investments. (These tax benefits were reduced in the 1996 federal budget, partly because some of these funds were receiving so much capital that they were unable to invest it all!) But these funds do represent a new role for labour organizations - as managers of venture capital. Quarter notes that by the end of 1994 the four largest labour investment funds represented nearly one third of all the formal venture capital in Canada.

Quarter views these developments as emblematic of the willingness of labour organizations to adopt a new approach in dealing with capital. This new willingness, he believes, stems from a recognition on the part of some labour organizations and some labour leaders that a variety of developments - such as free trade, global competition, high unemployment, and slow economic growth - have limited labour's ability to advance its agenda using the traditional adversarial approach, and that new alternatives must be sought. Obviously, one way of controlling capital is to become an owner of capital.

Of course, it should be recognized that this is far from a unanimous view within the labour community. For example, although the Quebec Federation of Labour and the Canadian Federation of Labour have established extremely successful labour investment funds, the largest labour federation, the Canadian Labour Congress, has not done so. Furthermore, very few labour organizations are willing to be proactive when it comes to worker buyouts, although this number is gradually increasing.

Of the eight chapters in the book, five are devoted to detailed case studies of worker buyouts, one per chapter. Although Quarter gives no explanation as to why 
these particular cases were selected, it appears that he wished to illustrate the great diversity even within this single category. Two of them - Pioneer Chain Saw and Algoma Steel - were motivated by their imminent closures. One Mainroad Contracting - came about because of the privatization of road maintenance services by the government of British Columbia. One - Nelco Mechanical - was a relatively healthy small firm which the owner was determined to convert to a worker cooperative. And the last case - CETAM - is a set of ambulance cooperatives in Quebec, for which the driving force was the Confédération des syndicats nationaux (CSN), which is philosophically committed to the establishment of worker cooperatives.

Each of these cases is thoroughly researched, based on direct interviews with many of the key participants, and each, in itself, tells a fascinating story. They are well-written, and convey the reality of the hurdles and obstacles, successes and failures. In general, four of the five are success stories (the exception was Pioneer Chainsaws, which achieved success under partial employee ownership, but was sold by the majority owner - at a substantial gain - and then closed by the new owner), although only two (Mainroad Contracting and CETAM) remain majority employee owned.

Chapter Seven focuses on labour investment funds, although it also includes discussion of some other labour-sponsored capital innovations and the role of union pensions funds as investors. Quarter notes that after the first labour investment fund - the Quebec Solidarity Fund, sponsored by the Quebec Federation of Labour - was established in 1983, the number of funds has gradually increased, starting with Working Ventures, created by the Canadian Federation of Labour in 1988. Since then funds have been established by the Manitoba, British Columbia, and New Brunswick Federations of Labour, as well as by individual unions or union groups, such as the Integrated
Growth Fund (United Food and Commercial Workers, Labourers International Union, the Amalgamated Clothing and Textile Union) or the First Ontario Labour Sponsored Investment Fund (Communications, Energy, and Paper Workers Union, United Steelworkers Union, Service Employees International Union).

Quarter points out that the key dilemma for these funds is combining investment objectives with social objectives. Most funds, such as Working Ventures, basically argue that any successful investment creates employment and is therefore socially beneficial, and evaluate investment opportunities on projected return on investment, while a few funds add some "social screens" to their investment decisions. Manitoba's Crocus Fund has gone the farthest in applying these screens, which include progressive management practices such as participative management, and a preference for a significant degree of employee ownership. Some funds, such as the Sportfund, sponsored by the Canadian Football League Players Association, appear to be set up mainly to capture the favourable tax treatment, and the promoters searched until they found a union to sponsor them. Among the more interesting analyses in this chapter is the analysis of return on investment in these funds, which, due to the favourable tax treatment, is quite favourable over the short to medium run, but probably less favourable over the longer run.

This chapter also includes a number of other interesting capital innovations, including the Cape Breton Labourer's Fund, which focuses on producing affordable housing for its members. The chapter concludes with a discussion of how some union-controlled pension funds are beginning to assume greater control over the management of these funds and to consider including social objectives in their investment decisions.

The final chapter revisits the broader implications, from a labour perspective, 
of blurring the labour-capital distinction. For example, will union members who invest in labour investment funds "support labour's political agenda (such as higher corporate taxes) if these policies have an adverse impact on the financial return to their fund?" For worker buyouts, will worker-owners "accept lower pay settlements than are necessary... [or] refuse to support industry-wide strikes"? Will worker-owners even continue to see the union as necessary? Although there are no clear answers to the first two questions, Quarter cites research indicating that, by and large, union members do not abandon the union after employee ownership.

Overall, this is a very thorough and thoughtful book. However, one notable omission is that it gives virtually no attention to partial employee ownership, after identifying it as one of three ways in which labour is "crossing the line" with capital. Perhaps this is because these plans are not as dramatic as worker buyouts, but the fact remains that employee stock plans will affect a great many more unionized employees than will worker buyouts. Another shortcoming, albeit a minor one, is an impression conveyed by the author that the labour movement is undergoing a massive shift in attitudes toward the traditional separation between labour and capital. In fact, with the exception of one or two unions, such as the CSN or the United Steelworkers, most unions are quite unenthusiastic about the idea of worker ownership, although they may not be as hostile as in the past. Even in regard to labour investment funds, the two largest federations, the Canadian Labour Congress and the Ontario Federation of Labour have not moved. There is still a great deal of traditional thinking in Canadian labour organizations. But however you look at it, Jack Quarter's book is a very useful contribution to our knowledge about a phenomenon that does seem destined to become increasingly common in the Canadian landscape.

RICHARD J. LONG University of Saskatchewan

\section{Under the Stars: Essays on Labor Relations in Arts and Entertainment} edited by Lois S. GRAY and Ronald L. SEEBER, Ithaca, N.Y., ILR Press, 1996, 207p., ISBN 0-87546-350-9 (hbk) and ISBN 0-87546-349-5 (pbk).

Is Hollywood ubiquitous? The dominance and pervasiveness of the U.S. motion picture and broadcasting industries would suggest that it is. Far-reaching and rapid technological change, increasingly concentrated and vertically integrated ownership structures and constantly evolving product markets have contributed to the shift towards globalization of popular entertainment since the 1970s. Without question, these changes have impacted dramatically on those who work within the arts and entertainment industries. It is perhaps surprising then that relatively little scholarly research has been undertaken which examines the industrial relations consequences of salient environmental developments, a point buttressed by the extensive use of industry sources to construct the current book's bibliography. The prior invisibility of the arts and entertainment sectors to industrial relations researchers itself raises an interesting question given that entertainment in its many forms is a highly visible and economically significant activity. Could an explanation of the dearth of research rest in part on a (false) premise that entertainment does not involve employment relationships? Whatever the reasons, Under the Stars is a welcome addition to the small but growing literature on industrial relations in arts and entertainment.

The editors set technological developments up as the primary explanatory factor in shaping patterns of industrial 